\title{
Ground maize cob as a dietary ingredient for broiler chickens in the tropics
}

\author{
A. Donkoh, E.K.D. Nyannor, A. Asafu-Adjaye and J. Duah \\ Department of Animal Science, \\ Kwame Nkrumah University of Science and Technology \\ Kumasi, Ghana
}

(Received 29 August 2002; accepted 20 December 2002)

\begin{abstract}
Ground maize cob (GMC) was characterized with respect to proximate, energy, fibre and mineral profile. The crude protein, fat, crude fibre, ash, NDF and ADF contents were, in $\mathrm{g} \mathrm{kg}^{-1} \mathrm{DM}: 25,4$, $347,24,687$ and 480, respectively, with metabolizable energy of $4.82 \mathrm{MJ} \mathrm{kg}^{-1} \mathrm{DM}$. In a feeding trial, diets containing $\operatorname{GMC}\left(25,50\right.$ and $\left.75 \mathrm{~g} \cdot \mathrm{kg}^{-1}\right)$ were fed ad libitum to 4 groups of 14-day-old commercial broiler chickens $(n=240)$ for a period of 6 weeks. Birds had free access to water. Growth performance data of birds fed diets containing GMC did not differ significantly from those on the control diet. Carcass yields were similar. No deaths nor health-related problems were recorded during the study. Haematological and blood biochemical indices were unaffected by the level of inclusion of the test ingredient. Dietary treatments had no impact on liver, gizzard and intestinal weights. It seems that in the tropics partial replacement of cereal and cereal by-products (maize and wheat bran) with GMC up to $75 \mathrm{~g} \cdot \mathrm{kg}^{-1}$ diet was possible.
\end{abstract}

KEY WORDS: maize cob, nutrient composition, broilers, growth performance

\section{INTRODUCTION}

The survival of the poultry industry in most developing countries in the future will, undoubtedly depend on the ability of poultry to compete with humans for the available food supply. Cereal demands for direct human use is expected to increase as more than half of the human race is undernourished and the world population is still increasing. Attention should therefore be given to the ability of poultry to utilize alternative, cheaper feedstuffs which are unacceptable to man. Such feedstuffs include fibrous cereal by-products as maize bran, rice bran, brewer's spent grains and wheat bran. 
However, the availability of these by-products fluctuates seasonally due to the unavailability of the main items from which these by-products are obtained. One potential feed ingredient that might be used to replace the more common, low energy, high fibre feedingstuffs in poultry diets is maize cob, a farm waste in several of the maize producing areas. Its utilization as animal feed at relatively low concentrations will minimise the pollution problem as well as reduce cost of feeding.

Regardless of its economic and nutritional status, it is important that investigations of the feeding potential of maize cob should take account of contaminants such as pathogenic bacteria. The level of spoilage microorganisms can be used to predict the potential shelf-life of the product (Bainbridge et al., 1996)

The aim of this study, therefore, was to assess the nutritive value of ground maize cob and the effect of replacing a portion of the maize and wheat an in broiler diets by ground maize cob on growth performance. The kinds and numbers of the microflora present in ground maize cob were also assessed.

\section{MATERIAL AND METHODS}

\section{Source of maize cob and processing method}

The maize cob used in the study was obtained from KNUST Commercial Farm, Kumasi (Ghana) after shelling. The cobs were further sun-dried to a moisture content of about $100 \mathrm{~g} \cdot \mathrm{kg}^{-1}$, ground in a hammer mill and stored in sacks until used in formulations.

\section{Dietary treatments}

Four experimental diets (Table 1) were formulated: a control diet containing no ground maize cob (GMC) and others in which GMC was incorporated at 25, 50 and $75 \mathrm{~g} \cdot \mathrm{kg}^{-1}$.

\section{Microbiological procedure}

Ten grams (10 g) of the GMC were homogenized and diluted in $90 \mathrm{ml}$ sterile maximum recovery diluent to obtain $1 \times 10^{-1}$ suspensions. The diluted suspensions of the GMC were subjected to surface viable microbial counts and isolation (Bainbridge et al., 1996) and identification (ICMSF, 1978). For microbial count and isolation, $1 \mathrm{~g}$ of GMC were inoculated onto selective agar (Nutrient agar for bacteria, McConkey agar for coliforms and Sabouraund agar for fungi), and the plates were incubated at $37^{\circ} \mathrm{C}$ for $48 \mathrm{~h}$. The number of colonies on the agar was counted. Plates supporting approximately 30-300 colonies were counted and the mean 
TABLE 1

Chemical composition of experimental growth diets

\begin{tabular}{lrrrr}
\hline \multirow{2}{*}{ Ingredients, $\mathrm{g} \mathrm{kg}^{-1}$} & \multicolumn{4}{c}{ Level of ground maize cob, $\mathrm{g} \mathrm{kg}^{-1}$} \\
\cline { 2 - 5 } & 0 & 25 & 50 & 75 \\
\hline Maize & 590 & 585 & 580 & 575 \\
Fish meal & 190 & 190 & 190 & 190 \\
Soyabean meal & 60 & 65 & 70 & 75 \\
Wheat bran & 130 & 105 & 80 & 55 \\
Ground maize cob & 0 & 25 & 50 & 75 \\
Oyster shell & 20 & 20 & 20 & 20 \\
Vitamin and mineral premix & 5 & 5 & 5 & 5 \\
Salt (NaCl) & 5 & 5 & 5 & 5 \\
Chemical analysis, g kg-1 DM & & & & \\
$\quad$ crude protein & 223.0 & 221.3 & 222.4 & 221.1 \\
$\quad$ crude fibre & 33.6 & 40.3 & 46.9 & 53.4 \\
$\quad$ Ether extract & 36.3 & 36.2 & 35.9 & 35.8 \\
Ca & 15.2 & 15.2 & 15.2 & 15.2 \\
$\quad$ P & 8.2 & 7.9 & 7.7 & 7.5 \\
ME, MJ kg-1b & 12.19 & 12.04 & 11.91 & 11.78 \\
\hline
\end{tabular}

${ }^{a}$ vitamin-premix supplied ( $\mathrm{kg}^{-1}$ diet): vit. A, 10,000 IU; vit. $\mathrm{D}_{3}$, $2000 \mathrm{IU}$; vit. E, $10 \mathrm{IU}$; vit. $\mathrm{K}, 3 \mathrm{mg}$; riboflavin, $4.4 \mathrm{mg}$; cobalamin, $0.05 \mathrm{mg}$; pantothenic acid, $8 \mathrm{mg}$; niacin, $16.5 \mathrm{mg}$; choline, $175 \mathrm{mg}$; folic acid, $0.5 \mathrm{mg}$; $\mathrm{Mg}, 2.3 \mathrm{mg}$; Fe, $30.5 \mathrm{mg}$; Zn, $50 \mathrm{mg}$; Co, $0.27 \mathrm{mg}$

${ }^{b}$ calculated from National Research (1994) and the ME value of maize cob estimated by the method of Sibbald (1986)

of triplicate plates noted. If growth was present after incubation, colonies were selected for identification. These procedures involved examination of colonial characteristics, morphology, motility, staining and biochemical properties using the guidelines of ICMSF (1978).

\section{Experimental animals and management}

A total of 240 unsexed 14-day-old commercial broiler chickens, with an initial body weight of $0.21 \mathrm{~kg}$, were allotted randomly to the four dietary treatments, in a completely randomized design. Each treatment group, consisting of 60 birds, was replicated in three deep litter pens of 20 birds per pen at a density of $0.26 \mathrm{~m}^{2}$ per bird. The study was conducted for 42 days (2-8 weeks of age). Birds had free access to feed and water.

\section{Parameters measured}

Among the traits measured were feed intake, growth rate, feed conversion efficiency (feed:gain ratio) and carcass parameters. Feed consumption and body weight were measured weekly for individual replicates of each dietary treatment. Morta- 
lities were also recorded. For carcass yield, four broilers from each of the 12 replicates were randomly selected at 56 days of age, starved of feed for about $18 \mathrm{~h}$, killed by cutting the jugular vein, exsanguinated, defeathered and eviscerated. Carcass yield was calculated from eviscerated weight and liveweight.

Four 6-week-old broiler chickens were used to determine the nitrogen-corrected true metabolizable energy $\left(\mathrm{TME}_{\mathrm{n}}\right.$ ) content of the GMC. Birds were fed ad libitum on a broiler finisher diet for 1 week prior to force-feeding (Sibbald, 1986). The birds were housed in individual cages with collection trays, fasted for $24 \mathrm{~h}$ and force-fed $30 \mathrm{~g}$ of the test ingredient. Four broilers were kept fasted during the assay to measure endogenous losses. Excreta were collected daily for $48 \mathrm{~h}$ after force-feeding, oven-dried at $60^{\circ} \mathrm{C}$ for $48 \mathrm{~h}$, equilibrated to ambient conditions, weighed and ground (Dale and Fuller, 1983). The GMC and the faecal samples were analysed for gross energy by bomb calorimetry. The $\mathrm{ME}_{\mathrm{n}}$ values for the experimental diets were, however, calculated from values given by the NRC (1994) and the determined $\mathrm{ME}_{\mathrm{n}}$ content of GMC.

\section{Chemical analysis}

Conventional methods (AOAC, 1990) were used to analyse the GMC and diets for their dry matter, crude protein, ether extract, ash and crude fibre contents. Acid detergent fibre (ADF), neutral detergent fibre (NDF) and hemicellulose (Goering and Van Soest, 1970) were also estimated on the GMC samples. Calcium, phosphorus, magnesium and potassium analyses followed the procedure of Fick et al. (1979).

\section{Blood collection and assays}

Blood samples were collected only at 6 and 8 weeks of age between 09.00 and $11.00 \mathrm{~h}$. Four birds from each of the 12 replicates were fasted for $12 \mathrm{~h}$ prior to the collection of blood specimens to avoid post-prandial lipemia (Kirk et al., 1990). Blood parameters studied included: red blood cell count (Maxwell, 1981), haemoglobin (Henry et al., 1974) and haematocrit or packed cell volume (Dacie and Lewis, 1975). The series of blood tests were performed on blood collected by vein or jugular venapuncture with ethylenediaminetetraacetic acid (EDTA, $1.5 \mathrm{mg} \mathrm{ml}^{-1}$ blood) as anticoagulant. Blood samples for serum cholesterol were allowed to clot to obtain serum and assayed in duplicate for total cholesterol by the method described by Varley (1962).

\section{Organ weights and histological studies}

The possible effects of GMC on the weight of some body organs were also assessed at 56 days of age. Four chickens from each treatment were randomly selected and killed by cervical dislocation. The liver, gizzard and intestine were excised, 
weighed immediately and expressed as $\mathrm{g} \cdot \mathrm{kg}^{-1}$ body weight. The liver was examined to determine whether the diets had resulted in any gross pathological changes. Liver sections were cut before staining with haematoxylin and eosin (Humason, 1979) and examined microscopically for any abnormalities in the cells.

\section{Statistical analysis}

The growth performance data measured were analysed using the general linear models procedure of SAS (1987). The data were subjected to regression analysis to show the effect of including GMC on performance.

\section{RESULTS AND DISCUSSION}

Results of the chemical analysis of the ground maize cob are shown in Table 2. The protein concentration and crude fat content as well as the metabolizable energy

TABLE 2

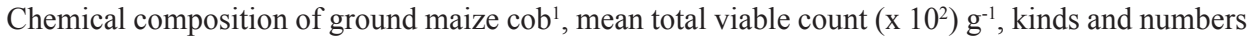
$\left(\mathrm{x} 10^{2}\right) \mathrm{g}^{-1}$ of microflora isolated from ground maize $\mathrm{cob}^{1}$

\begin{tabular}{lc}
\hline Item & Dry matter, $\mathrm{g} \cdot \mathrm{kg}^{-1}$ \\
\hline Proximate analysis & 896.0 \\
dry matter & 25.0 \\
crude protein & 4.0 \\
ether extract & 347.0 \\
crude fibre & 24.0 \\
ash & 496.0 \\
nitrogen-free extractives & 749.0 \\
starch+sugars+soluble polysaccharides & 687.0 \\
neutral detergent fibre & 480.0 \\
acid detergent fibre & 207.0 \\
hemicellulose & 4.0 \\
Ca & 0.2 \\
P & 2.4 \\
Mg & 0.013 \\
K & 4.82 \\
${ }^{2}$ Metabolizable energy, MJ kg $^{-1}$ & \\
Microbiological assay & 2.55 \\
mean viable count & \\
species & 1.65 \\
Proteus spp. & 0.95 \\
Mucor spp. & \\
\hline
\end{tabular}

${ }^{1}$ values are the means of three samples

${ }^{2}$ estimated according to the procedure of Sibbald (1986) 
value are lower but the crude fibre content is higher than other high fibre low energy feed ingredients used in poultry feeds, for example, brewer's spent grains, rice bran and wheat bran (NRC, 1994). Although diets high in fibre can limit energy intake (Lee et al., 1971), bulky diets may be more appropriate in the tropics where food (and energy) requirements are low. This is a consequence of high ambient temperatures (Howlinder and Rose, 1989). In this regard, GMC may be used to replace part of the high fibre ingredients, such as wheat bran and brewer's spent grains.

Ground maize cob contained $4.0 \mathrm{~g} \mathrm{Ca} \mathrm{kg}^{-1} \mathrm{DM}$ (Table 2) which is higher than that reported for brewer's spent grains $\left(2.9 \mathrm{~g} \mathrm{~kg}^{-1} \mathrm{DM}\right)$, rice bran $\left(0.8 \mathrm{~g} \mathrm{~kg}^{-1} \mathrm{DM}\right)$ and wheat bran $\left(1.4 \mathrm{~g} \mathrm{~kg}^{-1} \mathrm{DM}\right)$. It appears GMC can make moderate contributions to the calcium requirements of poultry.

The mean total viable microflora count of the GMC sample was $2.55 \times 10^{2} \mathrm{~g}^{-1}$ (Table 2). Microflora isolated from the GMC sample included Proteus spp. and $M u$ cor spp. The GMC sample was, however, free from pathogenic bacteria such as, faecal coliform bacteria, Salmonella, Staphylococcus spp. and Escherichia coli.

The results for the broiler feeding trial (Table 3) indicated no significant effects of dietary treatments on feed intake. Feed intake per bird for the 6-week period ranged from 3.34 to $3.45 \mathrm{~kg}$. The non-significant effect of GMC inclusion in the diet on feed intake suggests broiler chickens will consume diets containing up to $75 \mathrm{~g} \mathrm{GMC} \mathrm{kg}^{-1}$

TABLE 3

Effect of ground corn cob on broiler chicken performance from 14 to 56 days of age and blood components $^{1}$ and organ weights determined at 56 days of age

\begin{tabular}{|c|c|c|c|c|c|c|}
\hline \multirow{2}{*}{ Indices } & \multicolumn{4}{|c|}{ Level of ground maize cob, g. $\mathrm{kg}^{-1}$} & \multirow{2}{*}{ SEM } & \multirow{2}{*}{$\mathrm{r}$} \\
\hline & 0 & 25 & 50 & 75 & & \\
\hline Feed intake, kg & 3.38 & 3.45 & 3.34 & 3.36 & 0.11 & -0.46 \\
\hline Weight gain, $\mathrm{kg}$ & 1.81 & 1.89 & 1.79 & 1.74 & 0.07 & -0.52 \\
\hline Food: gain ratio & 1.87 & 1.82 & 1.87 & 1.93 & 0.04 & 0.56 \\
\hline Carcass yield, $\%$ & 80.0 & 81.0 & 79.0 & 80.0 & 0.70 & -0.32 \\
\hline Mortality, \% & 0 & 0 & 0 & 0 & - & - \\
\hline Red blood cell count, millions $\mathrm{m}^{-3}$ & 2.62 & 2.78 & 2.66 & 2.70 & 0.06 & 0.23 \\
\hline Haemoglobin, g $100 \mathrm{ml}^{-1}$ & 13.60 & 13.90 & 13.70 & 13.80 & 0.11 & 0.40 \\
\hline Haematocrit, \% & 34.40 & 34.90 & 34.55 & 34.70 & 0.18 & 0.33 \\
\hline Serum cholesterol, mg $100 \mathrm{ml}^{-1}$ & 88.45 & 88.86 & 87.95 & 88.65 & 0.34 & -0.06 \\
\hline Liver weight, $\mathrm{g} \mathrm{kg}^{-1} \mathrm{LBW}$ & 24.82 & 25.35 & 24.96 & 24.90 & 0.20 & -0.08 \\
\hline Gizzard weight, $\mathrm{g} \mathrm{kg}^{-1} \mathrm{LBW}$ & 22.62 & 23.15 & 22.95 & 23.00 & 0.19 & 0.54 \\
\hline Intestinal weight, $\mathrm{g} \mathrm{kg}^{-1} \mathrm{LBW}$ & 120.96 & 121.75 & 121.18 & 121.49 & 0.30 & 0.38 \\
\hline
\end{tabular}

${ }^{1}$ determined at 6 and 8 weeks of age

SEM - standard error of means

$r$ - correlation coefficient

LBW - live body weight 
The inclusion of varying levels of GMC in broiler diets did not have any significant impact on weight gains. Birds fed the diet which contained the highest amounts of GMC (50 and $75 \mathrm{~g} \mathrm{~kg}^{-1}$ ), had slightly lower weight gains compared to those fed the control and $25 \mathrm{~g} \mathrm{GMC} \mathrm{kg}^{-1}$ diets. Feed conversion efficiency declined with increasing levels of GMC. A declining feed conversion efficiency with the highest inclusion of GMC might be due to the increasing content of fibre and decreasing energy concentration in GMC diets. McDonald et al. (1995) reported that the fibre fraction of a food is one of the factors which have the greatest influence on its digestibility, and both the amount and chemical composition of the fibre are important. Higher amount of fibre in a diet decreases digestibility and consequently the performance. However, in this trial, the crude fibre content could not have been high enough to have significant impact on the performance of birds. The crude fibre level in the experimental diets (Table 1) ranged from 33.6 to $53.4 \mathrm{~g} \mathrm{~kg}^{-1}$. The similar growth performance attained by birds on the GMC-based diets, as compared with those on the GMC-free despite the possible undesirable effect with feeding diets containing high amounts of fibre may be attributed to the fact that as animals become older, they adapt to high fibre diets and digest them better (Sikka, 1990).

There was also no influence of GMC level on the carcass yield of broiler chickens processed at 56 days of age. No mortality or morbidity was observed in any of the treatment groups during the course of this study.

Blood haemoglobin concentration, PCV, serum cholesterol and liver, heart and intestinal weights were not significantly affected by added dietary GMC (Table 3 ). The findings under the conditions of this study showed no toxic effects in terms of gross tissue changes in the liver. The histological characteristics of the liver from birds on the controll diet were similar to those from birds on the GMC-containing diets.

It may be concluded that small amounts of GMC, in combination with other dietary ingredients, can be used in broiler diets to cut down on the use of maize and other ingredients such as wheat bran without sacrificing performance.

\section{ACKNOWLEDGEMENTS}

The authors thank F.A. Kwarteng and Mohammed Atiku Rasheed for technical assistance, T. Edusei for the chemical analysis and Ms. Gladys Ndziba for secretarial assistance. 


\section{REFERENCES}

AOAC, 1990. Official Methods of Analysis, Association of Official Analytical Chemists. 15th Edition. Arlington, VA

Bainbridge Z., Tomlins K., Wellings K., Westby A., 1996. Methods for Assessing Quality Characteristics of Non-Grains Starch Staples, Part 3. Laboratory Methods. Natural Resources Institute, Chatham (UK)

Church D.C., Pond W.G., 1988. Basic Animal Nutrition and Feeding. 3rd Edition. John Wiley and Sons Inc., pp. 302-303

Dacie J.V., Lewis S.M., 1975. Practical Haematology. 5th Edition. Churchill Livingstone, Edinburgh

Dale N.M., Fuller H.L., 1983. Oven drying vs. freeze drying of excreta in true amino acid availability and true metabolizable energy assay. Poultry Sci. 62, 1407-1408

Fick K.R., McDowell L.R., Miles P.H., Wilkinson N.S., Funk J.D., Conrad J.H., 1979. Methods of Mineral Analysis for Plant and Animal Tissues. 2nd Edition. Department of Animal Science, University of Florida, Gainesville

Goering H.K., van Soest P.J., 1970. Forage Fibre Analysis (Apparatus, Reagents, Procedures and some Applications). Agriculture Handbook No. 379, Agriculture Research Service, United States Department of Agriculture, Washington, DC, p. 20

Henry R.J., Cannon D.C., Winkelman J.W., 1974. Clinical Chemistry Principles and Technics. 2nd Edition. Harper and Row, New York

Howlinder M.A.R., Rose S.P., 1989. Rearing temperature and the meat yield of broilers. Brit. Poultry Sci. 30, 61-67

Humason G.L., 1979. Animal Tissue Techniques. 4th Edition. Freeman, San Francisco, CA, p. 661

ICMSF (International Commission on Microbiological Specifications for Foods), 1978. Microorganisms in Foods. I. Their Significance and Methods of Enumeration. 2nd Edition. University of Toronto Press, Toronto (Canada)

Kirk R.W., Bistner S.I., Ford R.B., 1990. Clinical procedures - blood collection. In: Handbook of Veterinary Procedures and Emergency Treatment. 5th Edition. W.B. Saunders Company, Philadelphia, pp. 448-455

Lee P.J.W., Gulliver A.L., Morris T.R., 1971. A quantitative analysis of the literature concerning the restricted feeding of growing pullets. Brit. Poultry Sci. 12, 413- 437

Maxwell M.H., 1981. Production of a Heinz body anaemia in the domestic fowl after ingestion of dimethyl disulphide: a haematological and ultrastructural study. Res. Vet. Sci. 30, 233-238

McDonald P., Edwards R.A., Greenhalgh J.F.D., Morgan C.A., 1995. Animal Nutrition. $5^{\text {th }}$ Edition. Addison Wesley Longman, Singapore

National Research Council, 1994. Nutrient Requirements of Domestic Animals. Nutrient Requirements of Poultry. 9th revised Edition. National Academy Press, Washington, DC

Sibbald I.R., 1986. The TME System of Feed Evaluation: Methodology, Feed Composition Data and Bibliography. Animal Research Centre Contribution 85-19, Ontario

Sikka S.S., 1990. Crude fibre is useful in rations. Misset, July/August, p. 29

Statistical Analysis Systems Institute Inc., 1987. Procedures Guide for Personal Computers. Version 6 Edition. SAS Institute, Cary, NC

Varley H., 1962. Practical Clinical Biochemistry. 3rd Edition. Whitefriars Press, London 


\section{STRESZCZENIE}

Mielone osadki kukurydziane - jako składnik diety dla kurcząt brojlerów w warunkach tropikalnych

Oznaczono podstawowy skład chemiczny, zawartość składników mineralnych oraz wartość energetyczną mielonych osadków kukurydzianych (GMC); ilość białka ogólnego, tłuszczu, włókna, popiołu, NDF i ADF wynosiła, $\mathrm{g} \cdot \mathrm{kg}^{-1}$ s.m.: 25, 4, 347, 24, 687 i 480, odpowiednio, przy zawartości energii metabolicznej 4,82 $\mathrm{MJkg}^{-1} \mathrm{~s} . \mathrm{m}$.

W doświadczeniu żywieniowym, przeprowadzonym na 240 kogutach podzielonych losowo na 4 grupy, udział GMC w dietach doświadczalnych wynosił 25, $50 \mathrm{lub} 75 \mathrm{~g} \cdot \mathrm{kg}^{-1}$; dieta kontrolna nie zawierała GMC. Pasze podawano do woli, a ptaki miały zapewniony stały dostęp do wody.

Nie stwierdzono istotnego wpływu diet doświadczalnych na pobranie paszy, przyrosty oraz wykorzystanie paszy w porównaniu z dietą kontrolną. Nie było również różnic w wydajności rzeźnej oraz wskaźnikach hematologicznych i biochemicznym krwi, a także masie wątroby, żołądka mięśniowego i przewodu pokarmowego. Nie wystąpiły żadne problemy zdrowotne.

Na podstawie otrzymanych wyników stwierdzono, że w warunkach tropikalnych można zastąpić część zbóż i zbożowych produktów ubocznych (otręby kukurydziane i pszenne) mielonymi osadkami kukurydzianymi do $75 \mathrm{~g} \cdot \mathrm{kg}^{-1}$ diety. 